Extensional Article

\title{
Glume blotch disease of wheat
}

FARIBA GHADERI ${ }^{\bowtie}$

Department of Plant Protection, Yasouj University, Yasouj, Iran

Received: 14.11 .2020

Accepted: 18.01.2021

Ghaderi F (2020) Glume blotch disease of wheat. Plant Pathology Science 9(2):108-

118. DOI: 10.2982/PPS.9.2.108.

\section{Abstract}

Glume blotch caused by the fungus Parastagonospora nodorum is an important disease of bread and durum wheat. The disease reduces the quantity and quality of wheat product. Disease history, pathogen morphology, and disease management methods, including crop rotation, plowing, post-harvest collection of plant debris , weed control, healthy seed culture or seed disinfection with a systemic fungicide, and cultivation of resistant cultivars are described.

Keywords: Wheat, Blotch, Management, Parastagonospora

$$
\begin{aligned}
& \text { مقاله ترويجى } \\
& \text { بيمارى لكه سفيد سنبله كَندم } \\
& \text { فريبا قادرى } \\
& \text { گروه كياهيزشكى، دانشگاه ياسوج، ياسوج }
\end{aligned}
$$

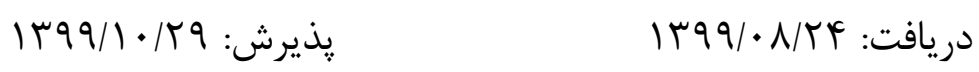

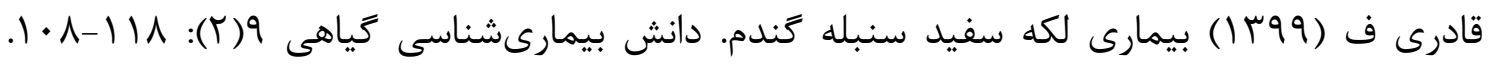

$$
\begin{aligned}
& \text { DOI:10.2982/PPS.9.2.108. } \\
& \text { جكيده }
\end{aligned}
$$

$\triangle$ fghaderi2003@yahoo.com 
كندم مهممترين محصول كشاورزى است و نقش بسيار بارز و جشمكيرى در تغذيه مردم جهان و ايران دارد. اين محصول بيشترين سطح زير كشت را در جهان به خود اختصاص داده است ( Webster and 1992 Gunnell). بىشك يكى از مهممترين عواملى كه مىتواند در كاهش عملكرد كندم تأثير گذار باشد، شيوع بيمارىهاى قارجى متنوعى است كه اندامهاى مختلف آن را تحت تأثير قرار داده و باعث كاهش كمى و كيفى اين گياه مى گردند.

Parastagonospora nodorum (Berk.) Quaedvl., بيمارى لكه سفيد سنبله كندم ناشى از يكى از بيمارىهاى مههم كندم در دنيا Verkley \& Crous (=Septoria nodorum (Berk.) Berk.) است (Eyal et al. 1987). بيمارى از سوئد، سوئيس، آلمان، فرانسه، ايالات متحده و استراليا گزارش شده است (Weber 1922). اين بيمارى انتشار جهانى دارد و گزارشهايى از خسارت اين بيمارى روى كندم در كانادا (Machacek 1945)، آرزانتين، هند، برزيل، ارويا (Scharen 1964) آفريقا و آسيا منتشر شده است. كاهش عملكرد ساليانه گَندم در اثر اين بيمارى در (Saari and Wilcoxson 1974) دنيا حدود نه ميليون تن تخمين زده شده است. بيمارى نخستين بار در ايران از استان كلستان

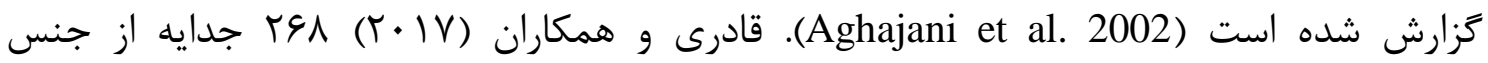
Parastagonospora

خوزستان، كلستان و كهيلويه و بويراحمد جداسازى و دو كونه P. nodorum Parastagonospora avenae (A.B. Frank) Quaedvl., Verkley \& Crous (=Septoria Phalaris راز شناسايى نمودهاند. همجنين P. nodorum avenae A.B. Frank) arundinacea

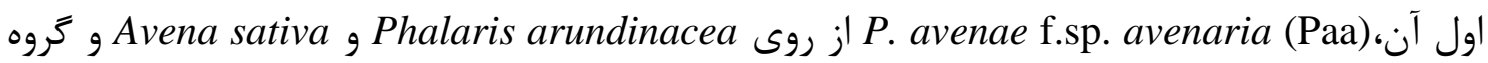
دوم، Promus hordeaceus (Phalari arundinacea P. avenae f.sp. tritici5 (Pat5 از روى Aegilops tauschii غيرجنسى و تأييد مولكولى آنها بر اساس توالىيابى زن بتازايلوسيداز انجام گرفت و گروههاى Pat5 و براى نخستين بار از ايران گزارش شدند و همجنين تمامى گَندميان گزارش شده، بهعنوان Paa ميزبانهاى جديد براى گونههاى گزارش شده در ايران و دنيا معرفى شدند (Ghaderi et al. 2017). همجنين Parastagonospora dactylidis W.J. Li, Camporesi, Bhat \& K.D. Hyde از روى علفهاى هرز Aegilops tauschii و Bromus hordeaceus Phalaris arundinacea، براى نخستين بار در ايران گزارش شده است (Ghaderi and Razavi 2018). 


\section{نشانهاى بيمارى}

بيمارى لكه سفيد سنبله گَندم در دنيا به Stagonospora nodorum blotch (SNB) معروف شده است. در اين بيمارى سنبله، ساقه، غلاف برگ و برگها آلوده مىشوند. نشانهاى اوليه شامل نقطههاى زردى هستند كه معمولاً روى برگهاى يائينى و در تماس با سطح خاك ديده مىشوند. بلدتريج بهصورت لكههاى بيضى يا عدسى شكل به رنگ قهوهاى سوخته با هالهاى زرد رنگ روى يهنك برگ ظاهر مىشوند (شكل I، A). در صورت آلودگى شديد، لكههاى توسعهيافته، به هم متصل مىشوند و ظاهرى مرده در بافت گياه ايجاد مى گردد. پس از مدتى، اندامهاى باردهى قارج (ييكنيديومها) به رنت قهوهاى روشن و بهصورت دستهاى يراكنده در سطح بافت آلوده ظاهر مىشوند. آلودگى غلافهاى برى بهصورت لكههاى قهوهاى تيره وسيعى ديده مىشود و در صورت آلودگى برى ״رجم ممكن است باعث بدشكلى سنبله گردد. قهوهاى شدن و جروكيده شدن گرههاى آلوده ساقه نيز از نشانه بيمارى مىباشد و سطح ساقه آلوده با ريكنيديومهاى قارج بلهورت خالدار درمىآيد. شدت اين آلودگى باعث خم شدن ساقه و خوابيدگى آن درست در بالاى گرههاى آلوده مىشوند. همجنين نشانه سوختكى از نوك گلومها و لماها شروع شده، به سمت يائين ييشروى مى گند كه بهتدريج بلهورت نوارهاى قهوهاى رنت ظاهر مىشوند (شكل )، B). پيكنيديومهاى خاكسترى تيره يا قهوهاى رنت قبل از اينكه سوختكى يك سوم طول كلوم (از انتها) را بيوشاند، ظاهر مىشوند اين اتفاق معمولاً دو تا سه هفته بعد از ظهور سنبله مىافتد. يُيكنيديومهاى روى كلوم، روى خطوط تقريباً راست تشكيل مىشوند. در شرايط مرطوب رشتهاى صورتى رنكى از دهانه پِيكنيديومهاى موجود بر روى برگها و حلومها خارج مىشود كه سيروس (Cirrhus) نام دارد كه حاوى توده بسيار فراوان پيكنيديوسيورهاى قارج هستند كه در داخل يك مايع غليظ زلاتينى از دهانه پيكنيديومها خارج مىشوند. توليدمثل جنسى قارج (سودوتسيوم) در اواخر فصل بلصورت نقطههاى ريز سياهرنت و برجسته در كنار پيكنيديومها بر روى سطح گلومهاى آلوده تشكيل مىشوند. در صورت آلودگى شديد، دانههاى توليد شده در سنبلههاى آلوده سبك وزن و ظاهرى جروكيده و بدشكل دارند (شكل ا، B). اين بذرها قادر به جوانهزنى هستند اما گياهجههاى ناشى از اين بذرها نيز دجار ضعف و يوسيدگى كولئويتيل شده، ظاهرى بدشكل و غيرعادى ييدا مى كنند. لازم به ذكر است كه بالاترين خسارت عملكرد اين بيمارى

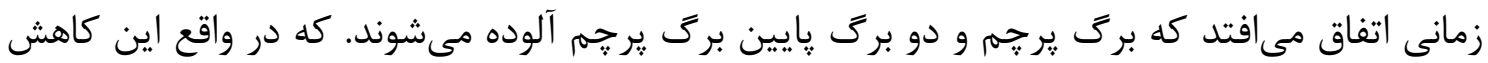
عملكرد به دليل كاهش سطح فتوسنتز كننده برى مىباشد كه نهايتاً مانع ير شدن دانه و موجب كاهش وزن دانهها مى گردد. اگر اين برگها قبل از مرحله خميرى نرم آلوده شوند، دانهها سبك وزن و

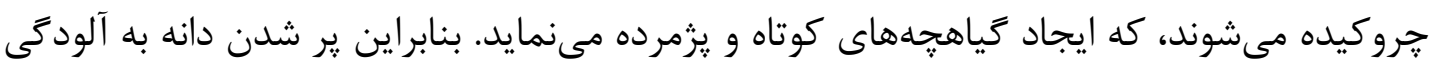




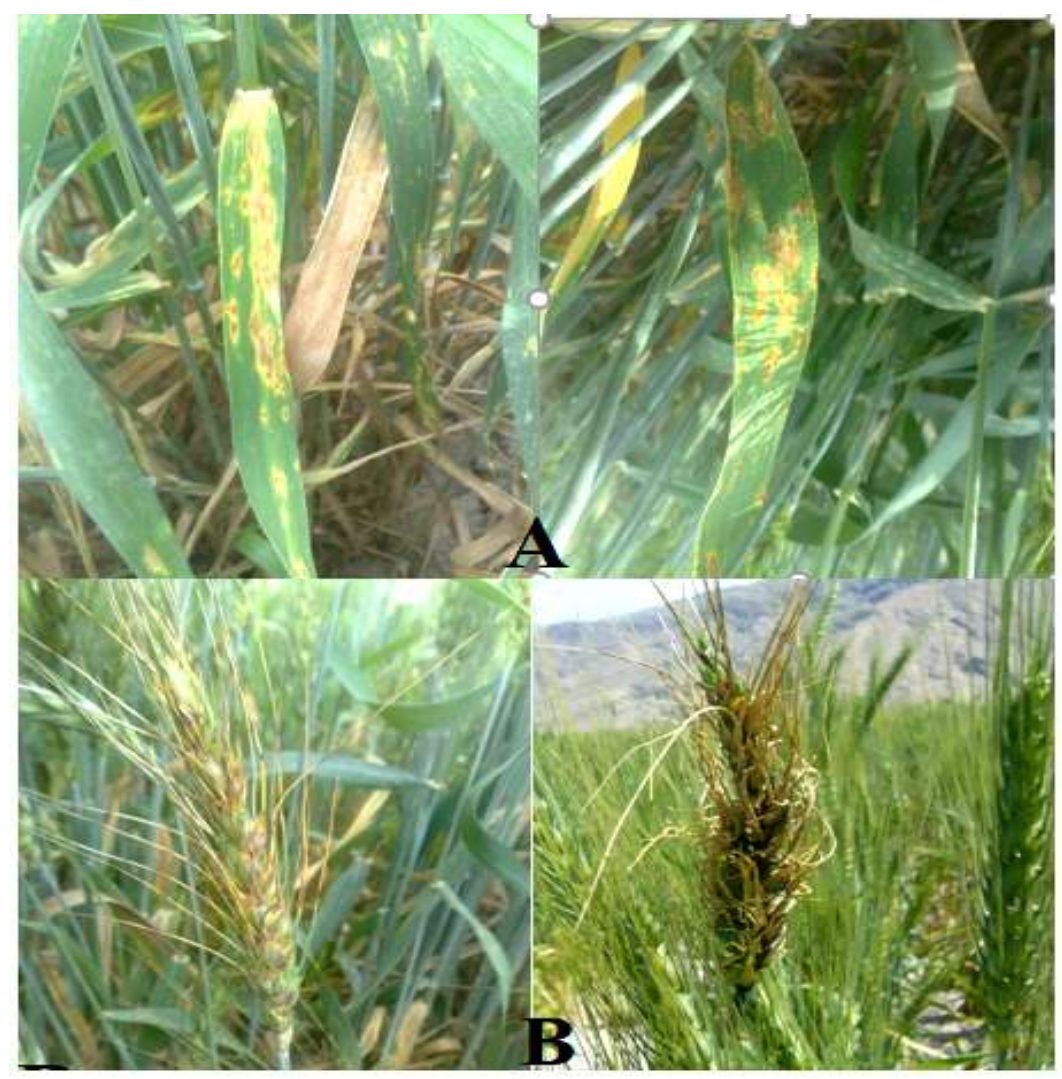

شكل ا. بيمارى لكه سفيد سنبله گَندم A (Parastagonospora nodorum). لكههاى بيضى يا عدسى شكل به رنَ قهوهاى سوخته با هالهاى زرد رنگ روى يهنك برى B. نشانه سوختگى از نوى

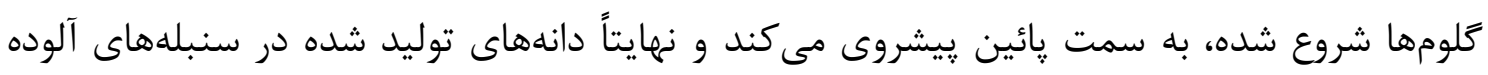

$$
\text { جروكيده و بدشكل مىشوند (اصلى) }
$$

Figure 1. Glume blotch disease of wheat (Parastagonospora nodorum) A. The symptom of infected leaves: dark-brown lesions expand and become oval (lens-shaped) with yellow halo, B. The symptom of infected ears: the lesion on a glume typically starts at the tip of the glume and progresses downward and infected glumes lead to shriveled kernels

Cunfer and Ueng 1999, Eyal et al. 1987, Solomon et al. ) برى پرجم و سنبله ارتباط دارد .(2006

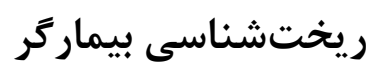

قارج Parastagonospora nodorum از رده Dothideomycetes، راسته Pleosporales و تيره Phaeosphaeriaceae

اهلى (T. durum Desf. and Triticum aestivum L.) و تريتيكاله مىباشند ( Solomon et al. 

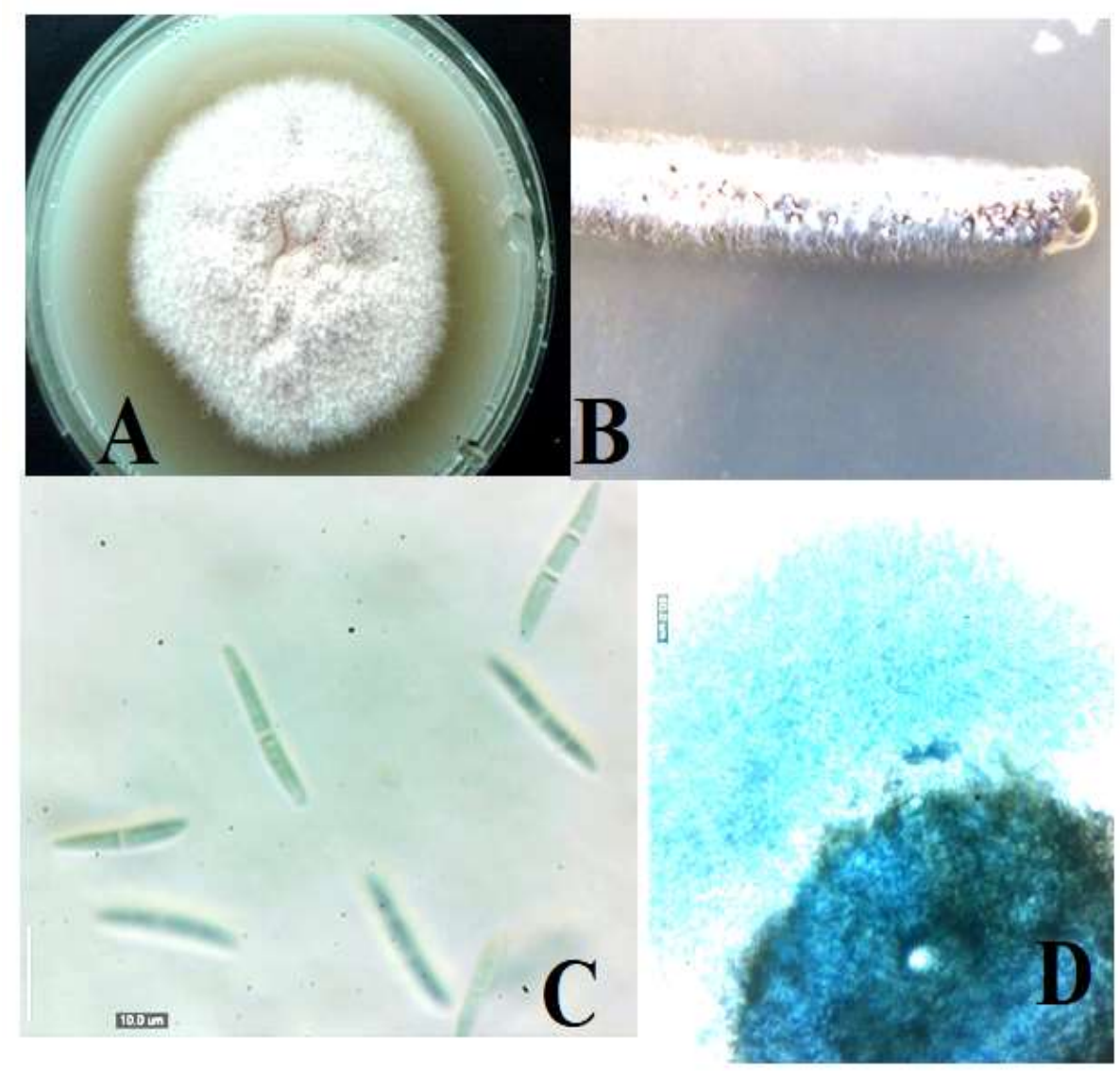

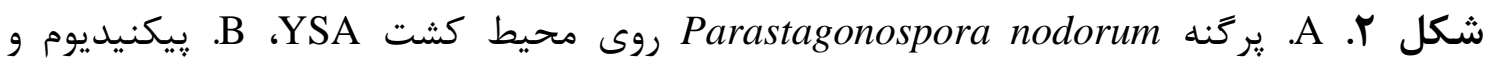
״يكنيديوسيور تشكيل شده روى كاه استريل كندم در محيط كشت WA C C. بيكنيديوسيورها

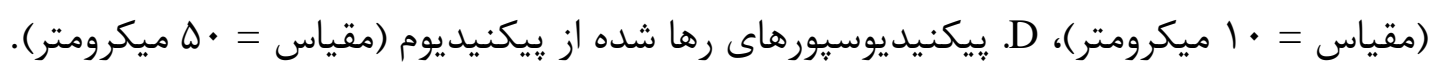

Figure 2. A. Colony of Parastagonospora nodorum on YSA, B. Pycnidia and pycnidiospores formed on sterilized wheat straws in WA Medium, C. Pycnidiospores $(\operatorname{Bar}=10 \mu \mathrm{m})$, D. Pycnidiospores released from pycnidium $(\operatorname{Bar}=50 \mu \mathrm{m})$.

يركنه قارج روى محيط كشت عصاره مخمر - سوكروز- آكار (Yeast Sucrose Agar- YSA) به رنگ سفيد ديده ميشود و بعد از هفت روز • ا ميلىمتر رشد ميكند (شكل r، A). توليدمثل غيرجنسى اين قارج به شكل ييكنيديوم است، پيكنيديومها زير إيدرمى، نيمه كروى با يك منفذ مركزى و با دو تا سه لايه مىباشد، ريكنيديوسيورها روشن، راست يا خميده، از دوكىشكل تا استوانهاى شكل متغير بوده و در هر دو طرف گرد و بندرت باريك مىباشند. تعداد ديواره عرضى در هر كنيديوم از يك تا دو

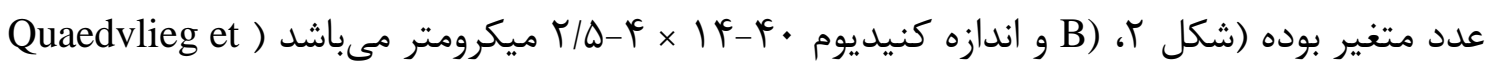
al. 2013 . توليدمثل جنسى اين قارج بهصورت آسكوكارب از نوع سودوتسيوم است. سودوتسيومها فرورفته در بافت، گرد، قهوهاى تا سياه در محيط كشت با ديوارهاى با و-س لايه و داراى يك سوراخ با 
دهانه كوجى مىباشد. آسكها گرزى شكل، راست يا خميده با هشت آسكوسيور با ديواره ضخيم، آسكوسيورها روشن تا قهوهاى كمرنت با سه ديواره كه سلول يكى مانده به آخر متورم بوده،

يارافيزهاى كاذب نخىشكل، روشن و ديوارهدار مىباشند (Shoemaker and Babcock 1989).

\section{زيستشناسى بيمارگر}

بهترين شرايط همد گيرى اين بيمارى آب و هواى مرطوب و بادى هست (Shah et al. 1995). در طول دوره گرم و خشك (اواخر بهار)، توسعه لكهها و ييكنيديومها متوقف مىشود (Tiedemann 1996). به نظر مىرسد بيمارگر در شرايط سرد قادر به تكثير مناسب نمىباشد. در طول ماههاى زمستان اين قارج بلهورت غيرفعال در گياه باقى مىمانند و فرايند آلودگى در بهار اتفاق مىافتد زيرا براى آلودگى ع تا

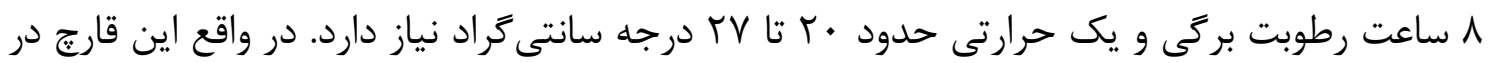

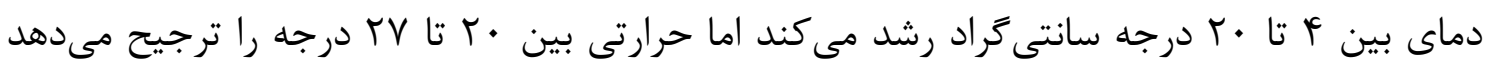

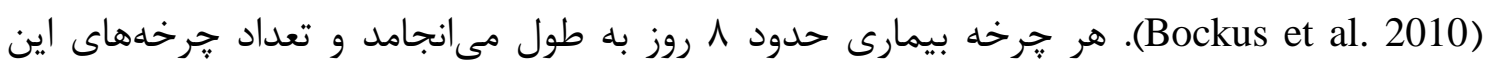
بيمارى به شرايط آب و هوايى مطلوب اين قارج بستخى دارد. ييكنيديوسيورها بلوسيله قطرات باران تا ارتفاعى حدود دو متر و فاصلهاى حدود rو سانتىمتر يراكنده مىشوند اما باد همراه با قطرات باران، باعث جابجايى هاتها در ارتفاعى حدود ץ متر و فاصلهاى حدود • متر مى مردد (Brennan et al. 1985). شش منبع بالقوه براى توليد زادمايه اوليه قارج P. nodorum توصيف شده است. سه منبع بالقوه مربوط به مرحله غيرجنسى است كه شامل ييكنيديوسيورهاى روى كاه و كلش كندم، ميزبان واسط و بذرها آلوده مىباشد. سه منبع بالقوه مربوط به مرحله جنسى است كه شامل آسكوسيورها روى كاه و كلش، ميزبان واسط و بذرهاى آلوده مىباشد (Shah et al. 1995). اين قارج به مدت سه سال روى كاه و كلش باقى مىماند. اين قارج از بذرهايى كه مدت Iل سال در انبار ذخيره

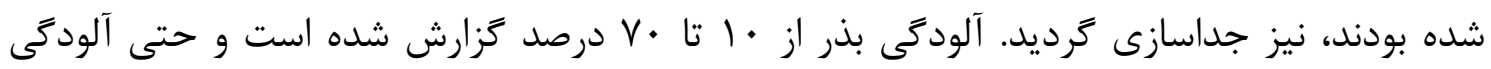
• 1 درصد بذرها و شرايط محيطى مناسب (رطوبت، دما و باد) مىتواند باعث إيدمى شود كه اين مسئله نقش بذر را به عنوان يك منبع بالقوه براى توليد زادمايه اوليه ثابت مىكند (Eyal et al. 1987). اين قارج مىتواند گياهجه، گياه بالغ و سنبله را آلوده نمايد اين آلودگى باعث كاهش سطح برى سبز مىشود كه از فعاليت فتوسنتز در گياه جلوگيرى مى مند (Bockus et al. 2010). نرخ فتوسنتز يك روز بعد از آلودگى كاهش مىيابد اما تجزيه كلرويلاست ع تا 9 ورز بعد از آلودگى شروع مىشود. آلودىى گياهان از طريق روزنهها يا بهصورت نفوذ مستقيم با تجزيه آنزيمى اتفاق مىافتد. اين قارج از آنزيمهاى تجزيهكننده ديواره سلولى شامل آميلاز، يكتين متيل 
استراز، زايلاناز، پِليعالاكتوراناز و سلولاز استفاده مى كند كه از اين تركيبات همراه با توكسينهاى اختصاصى ميزبان در طول فرايند آلودىى استفاده مىشوند (O'Reilly and Downes 1986). اولين

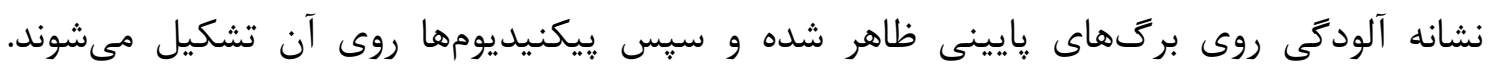

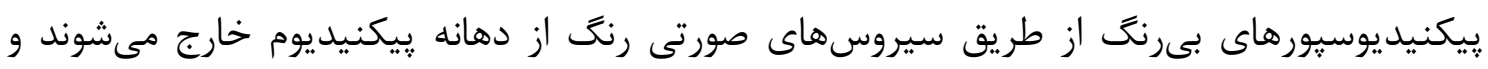
روى بركهاى جوان قرار مى كيرند. زل سيروس، حاوى يروتئينهاى غليظ و كلوسيدها است كه از

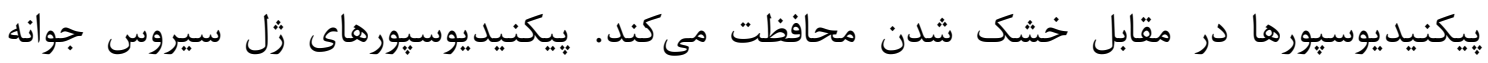

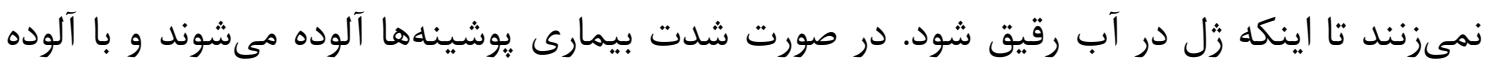
شدن يوشينهها اين بيماركر مىتواند بذرها را آلوده نمايد و اين بذرها مىتوانند بلعنوان منبع مايه تلقيح نقش داشته باشند (Bockus et al. 2010).

\section{دامنه ميزبانى بيماركر}

Poa pratensis L., Bromus inermis تاكنون از روى كندم، جو، ترتيكاله، جاودار، P. nodorum Cynodon dactylon Aegilops cylindrical Auct. “Elymus repens Gould. ‘Leyss. 9 Agropyron desertorum Schultes ، Lolium perenne L. ‘Hordeum pusillum Nutt. ‘Pers. McDonald et al. 2012, DeWolf and Francl 2000, Ghaderi et al. ) Phalaris arundinacea 2017 ) كزارش شده است.

$$
\text { مديريت بيمارى }
$$

بيمار گر روى بقاياى كياهى زمستان گذرانى مى كند، بنابراين حفظ بقاياى بوتهاى بيمار و علفهاى هرز در سامانهاى كشاورزى حفاظتى ممكن است منجر به شيوع و گسترش بيمارى تردد، لذا تناوب با

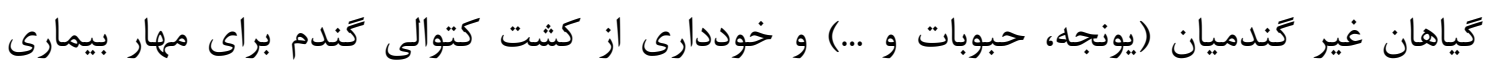
توصيه مى كردد (Eyal et al. 1987, Eyal 1981).

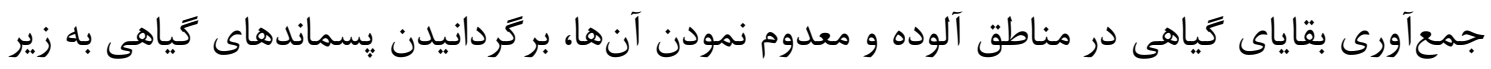

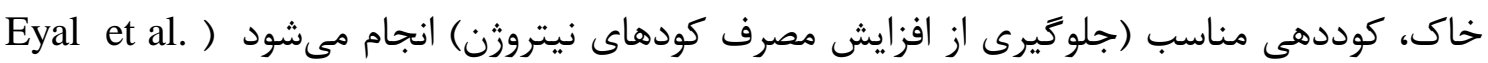
. (Tiedemann 1996, 1987 كاشت بذر سالم و در صورت عدم اطمينان از سالم بودن بذر، تيمار بذر با قارجكشهاى جذبى مىتواند در كاهش بيمارى در شرايط مزرعهاى مؤثر باشد ( Eyal et al. 1987, Eyal 1981).

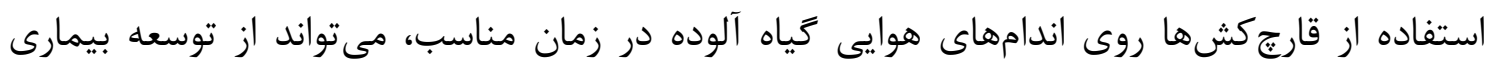

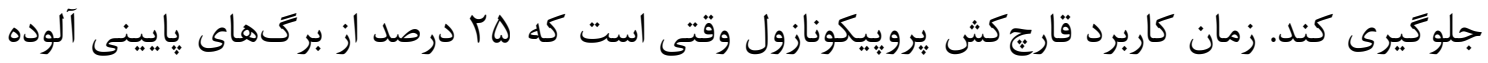


مىشوند و روى آن مؤثر است. اين قارجكش در دو مرحله و به فاصله ·r روز در ايالات متحده، نيوزيلند، استراليا و ارويا استفاده مىشود (Hennouni et al. 2012). استفاده از رقمهاى مقاوم در سالهاى اخير موردتوجه قرار گرفته است. كروييناسكاى و همكاران

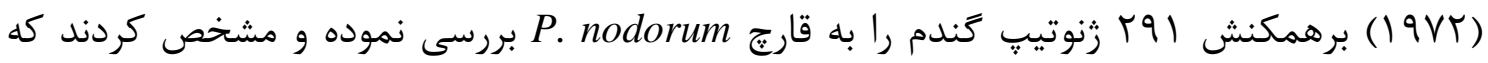
عا زنوتيب سطوح نسبتاً مقاومى را دارا مىباشند (Krupinsky et al. 1972). راييلى و دلهوتال (9^9 (1) دوكولتيوار Razon و R82 را مقاوم به P. nodorum در ايالات متحده معرفى كردند

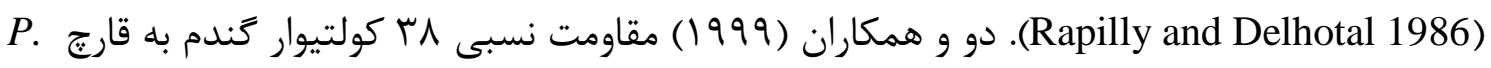
را ارزيابى و هشت كولتيوار با مقاومت متوسط را معرفى نمودند (Du et al. 1999). كانفر و

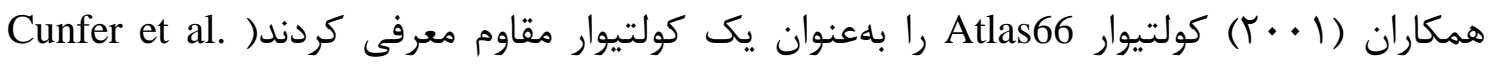

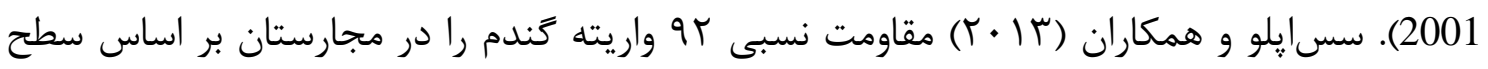
آلوده برى بررسى نمودند و • ا واريته مقاوم به Podorum را ذكر نمودند (Cseplo et al. 2013).

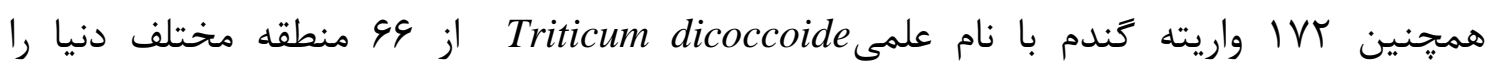
جمع آورى نمودند و بعد از ارزيابى مقاومت نسبى، عسا واريته را مقاوم به قارج Podorum معرفى نمودند و T. dicoccoide را بهعنوان يك منبع زنتيكى مناسب در مقاومت به لكه سفيد سنبله كندم ذكر كردند (Cseplo et al. 2013). قادرى و همكاران (צا • r) واكنش צr رقم گَندم به جدايdهاى Podorum، مورد بررسى قرار دادند و مشخص كردند كه جمران كاملاً حساس، استار، بهرنگ، كوير، الوند، بزوستايا، هيرمند و كاسيارد نيمه حساس، ياواروس، توس، شيرودى، سياهان، قدس، كاسكوزن و بك كراس روشن مقاوم و الموت،

فلات، شهريار، شيراز، مرودشت، اترك و نويد نيمه مقاوم مىباشند (Ghaderi et al. 2016). با اين حال به نظر مىرسد كه منابع مقاومت بين ارقام گَندم به بيمارى لكه سفيد سنبله گَندم بسيار محدود مىباشد و تعداد زيادى از محققين به دنبال مقاومت مختلف روى گونههاى ديكر جنس Triticum

\section{نتيجه كيرى}

قارج Parastagonospora nodorum يك قارج بيمار گر مههم روى گندم است كه ايجادكننده بيمارى لكه سفيد سنبله گَندم است و خسارت قابل ملاحظهاى به اين محصول در دنيا وارد مى كند. ميزبانهاى اصلى اين بيمارگر، كندمهاى اهلى (T. durum and Triticum aestivum) گندم، جو، ترتيكاله، جاودار، و تعدادى از علفهاى هرز تيره كَندميان مىباشند. اين بيمارگر به تمام قسمتهاى 


$$
\begin{aligned}
& \text { هوايى گياه (برگ، ساقه، گلوم و ...) حمله مىنمايد و در صورت آلودگى شديد، دانههاى توليد شده در } \\
& \text { سنبلههاى آلوده سبك وزن و ظاهرى جروكيده و بدشكل هستند و منجر به كاهش كمى و كيفى دانه } \\
& \text { مىشود. جهت مديريت بيمارى سوختكى سنبله روشهاى تناوب، شخم، جمعآورى يا دفن بقاياى } \\
& \text { بوتههاى بيمار، حذف علفهاى هرز، كشت بذر سالم، ضدعفونى بذر با قارجششهاى جذبى و كشت } \\
& \text { رقمهاى مقاوم קيششنهاد مىشود. }
\end{aligned}
$$

\section{References}

1. Aghajani MA, Kazemi H, Dehghani MA, Rajabi S, Nuralahi K (2002) Study on distribution and importance of Septoria glum blotch of wheat in some provinces of Iran. Abstract book the first International of wheat Congress, Tehran, p.37.

2. Bockus WW, Bowden RL, Hunger RM, Morrill WL, Muray TD, Smiley RW (2010) Compendium of Wheat Disease and Pests. (Third edition), APS Press, MN, USA, 171p.

3. Brennan R.M, Fitt G, Taylor GS, Colhoun J (1985) Dispersal of Septoria nodorum pycnidospores by simulated rain and wind. Journal of Phytopathology 112:291-297.

4. Cunfer B, Ueng P (1999) Taxonomy and identification of Septoria and Stagonospora species on small grain cereals. Annual Review Phytopathology 37:267-284.

5. Cunfer B, Johnson MJW, Buntin GD, Barnett RD, Roberts JJ (2001) Registration of four soft red winter wheat germplasms resistant to Stagonospora nodorum and other foliar pathogens. Crop Science 41:1373-1374.

6. Cseplo M, Csosz M, Gal M, Veisz O, Vida G (2013) Seedling resistance to Stagonospora nodorum blotch in wheat genotypes. Czech Journal of Genetics and Plant Breeding 49:77-85.

7. De Wolf ED, Francl LJ (2000) Neural network classification of tan spot and Stagonospora nodorum blotch infection periods in a wheat field environment. Phytopathology 90:108-113.

8. Du CG, Nelson LR, McDaniel ME (1999) Diallel analysis of gene effects conditioning resistance to Stagonospora nodorum (Berk.) in Wheat. Crop Science 39:686-690.

9. Eyal Z (1981) Integrated control of Septoria diseases of wheat. Plant Disease 65:763768

10. Eyal Z, Sharen AL, Prescott JM, Van Ginkel DM (1987) The Septoria diseases of wheat: concepts and methods of disease management. Mexico, DF, CIMMYT.

11. Hennouni N, Djeber MR, Berrebba HD (2012) Effect of systemic fungicide (combination of Cyproconazole and Propiconazole) newly introduced in Algeria on 
Septoria of two varieties of wheat (Triticum durum Desf.). Advances in Environmental Biology 6:1433-1442.

12. Krupinsky JM, Schillinger JA, Scharen AL (1972) Resistance in wheat to Septoria nodorum. Crop Science 12:528-530.

13. Quaedvlieg W, Verkley GJM, Shin HD, Barreto RW, Alfenas AC, Swart WJ, Groenewald JZ, Crous PW (2013) Sizing up Septoria. Studies in Mycology 75:307390.

14. Ghaderi F, Sharifnabi B, Javan-Nikkhah M (2016) Assessment of partial resistance of wheat cultivars to Phaeosphaeria nodorum in Iran. Journal of Applied Entomology and Phytopathology 84:55-66.

15. Ghaderi F, Sharifnabi B, Javan-Nikkhah M (2017) Introduction of some species of Parastagonospora on poaceous plants in Iran. Rostaniha 18:150-165.

16. Ghaderi F, Razavi M (2018) Identification of the species Parastagonospora dactylidis on poaceous plant in Iran. Mycologia Iranica 5:35-41.

17. Machacek JE (1945) The prevalence of Septoria on cereal seed in Canada. Phytopathology 35:51-53.

18. McDonald, MC, Razavi M, Friesen TL, Brunner PC, McDonald BA (2012) Phylogenetic and population genetic analysis of Phaeosphaeria nodorum and its close relative indicate cryptic species and an origin in the Fertile Crescent. Fungal Genetics and Biology 49:882-895.

19. Miyakei I (1909) Studies on the parasitic fungi of rice in Japan. Botical Magazine Tokyo 23:85-97.

20. O'Reilly P, Downes MJ (1986) Form of survival of Septoria nodorum on symptomless winter wheat. Transactions of the British Mycological Society 86:381385 .

21. Rapilly F, Delhotal P (1986) Surla durabilite de resistance partielles Septoria nodorum Berk.chez le ble etudes prospectives realisees par la simulation. Agronomie 6:325-336.

22. Saari EE, Wilcoxson RD (1974) Plant disease situation of high-yielding dwarf wheat in Asia and Africa. Annual Review of Phytopathology 12:49-68.

23. Shah D, Bergstrom GC, Ueng PP (1995) Initiation of Septoria nodorum blotch epidemics in winter wheat by seedborne Stagonospora nodorum. Phytopathology $85: 452-457$.

24. Scharen AL (1964) Environmental influence on development of glume blotch in wheat. Phytopathology 54:300-303.

25. Shoemaker RA, Babcock CE (1989) Phaeosphaeria Canadian Journal of Botany 67:1500-1599. 
26. Sprague R (1950) Disease of Cereal and Grasses in North America. Ronald Press, New York. 538p.

27. Solomon PS, Lowe RGT, Tan KC, Waters ODC, Oliver RP (2006) Stagonospora nodorum: cause of Stagonospora nodorum blotch of wheat. Molecular Plant Pathology 7:147-156.

28. Tiedemann AV (1996) Single and combined effects of nitrogen fertilization and ozone on fungal leaf diseases on wheat. Journal of Plant Diseases and Protection 103:409-419.

29. Xu SS, Friesen TL, Cai X (2004) Sources and Genetic Control of Resistance to Stagonospora nodorum Blotch in Wheat. pp. 449-469. In: Recent Research Development in Genetics and Plant Breeding. Vol. 1. Research Signpost, Kerala, India.

30. Weber GF (1922) Septoria diseases of wheat. Phytopathology 12:537-585.

31. Webster RK, Gunnell PS (1992) Compendium of Wheat Diseases. APS Press, MN, USA, 62p. 